\title{
“ÜKS VÕIMSAMAID RELVI VÕITLUSES KODANLISE NATSIONALISMI VASTU ON KINDLASTI EESTI AJALUGU..." EESTI VABARIIGI PERIOODI UURIMISEST Eesti NSV Teaduste AKadeemia ajaloo INSTITUUDIS AASTATEL 1946-1950
}

\author{
Tõnu Tannberg
}

\begin{abstract}
Ajalooteaduse uutele rööbastele seadmine algas kohe pärast Eesti taasokupeerimist 1944. aasta hilissügisel. 1944. aasta detsembri alguses kogunes Tallinnas Eestimaa Kommunistliku (bolševike) Partei Keskkomitee (EK(b)P KK) pleenum, et läbi arutada ja laiema avalikkuse ette tuua Moskva poolt 30. oktoobril 1944. aastal Üleliidulise Kommunistliku (bolševike) Partei Keskkomitee (ÜK(b)P KK) orgbüroo otsusega paika pandud sovetiseerimisprogrammi põhilised seisukohad. ${ }^{1}$ Viidatud Moskva otsusega algas "suur võitlus" nn kodanliku natsionalismi vastu, mille üks teravik oli suunatud sõjaeelse Eesti vabariigi mustamisele ja ühiskondlikust teadvusest väljajuurimisele.

Olulist rolli hakkas selles "võitluses" etendama ajalugu. Sealjuures seisis uus režiim ajalooteaduse edenemist silmas pidades silmitsi üldise küsimusega, kas omariikluse periood väärib üldse uurimist või mitte? Kui esmapilgul võiks arvata, et Eesti vabariigi ajaloo uurimise teemat ei peetud kohe Eesti taasokupeerimise järel oluliseks, siis tegelik olukord oli teistsugune - omariikluse periood osutus igati parketikõlbulikuks uurimisteemaks.

Käesolev artikkel püüabki leida vastust küsimusele, miks ja kelle initsiatiivil pöörati sovetiseerimisprotsessi algfaasis omariikluse perioodile võib-olla oodatust rohkem tähelepanu? Sellega seoses käsitletakse põgusalt Eesti omariikluse perioodiga seotud uurimisteemade ja nende täitjate valikut, uute Eesti ajaloo üldkäsitluste koostamist ning nõukoguliku periodiseerimisskeemi väljatöötamist. Kõik need teemad seob suuresti üheks
\end{abstract}

\footnotetext{
1 Tõnu Tannberg, ““Selle büroo ülesandeks on ...”. ÜK(b)P Keskkomitee Eesti büroo osast Eesti NSV sovetiseerimisel aastail 1944-1947", Nõukogude Eesti külma sõja ajastul, koost Tõnu Tannberg, Eesti Ajalooarhiivi toimetised 23(30) (Tartu, 2015), 11-30.
} 
tervikuks Hans Kruusi isik, kes ei etendanud keskset rolli mitte ainult ajalooteaduse vallas, vaid juhtis laiemalt kogu teaduskorralduse nõukogustamist. Vaatluse alla on võetud ajavahemik 1944. aasta lõpust kuni 1950. aastani, mil seoses Eesti NSV poliitilise juhtkonna sundvahetusega tõrjuti kõrvale ka peaaegu kõik senised ajaloo uurimist korraldanud võtmefiguurid. See omakorda tõi endaga kaasa ka olulised rõhuasetuste muutused teemade valikus. Käsitlus on Eesti NSV Teaduste Akadeemia ajaloo instituudi keskne, kuna just sellest asutusest sai sõjajärgsetele aastatel juhtiv ajaloo uurimiskeskus Nõukogude Eestis.

Ajalooteaduse nõukogustamist on senises ajalookirjanduses mitmed autorid käsitlenud. Esiletõstmist väärivad siinkohal Teet Veispaki, Jaan Unduski, Olaf Kuuli ja Ants Viirese uurimused, mis analüüsivad ajalooteaduses toimunud muutusi sõjajärgsel perioodil, peatumata lähemalt Eesti vabariigi uurimise teemal. ${ }^{2}$ Sama saame öelda ka Helen Lausma-Saare teemakohase magistritöö kohta. ${ }^{3}$ Põhjalikult on sõjajärgseid olusid ajalooteaduse vaatepunktist analüüsinud Jüri Kivimäe Hans Kruusile pühendatud monograafias. ${ }^{4}$ Ülal loetletud uurimustele tugineb ka alljärgnev käsitlus, kuid lisaks on kasutatud uudset arhiiviainest Rahvusarhiivist, Tartu Ülikooli raamatukogu käsikirjade osakonnast ja Eesti Teaduste Akadeemia arhiivist.

Sõjajärgse Eesti NSV “ajaloorinde”, kui kasutada ajastu retoorikat, ülemjuhatajaks oli 1940. aasta juunipöördega kaasa läinud Hans Kruus, kes kuulus tollase liiduvabariigi juhi Nikolai Karotamme lähikondlaste sekka. H. Kruusi üheks "vastutusvaldkonnaks" liiduvabariigi juhtkonnas oligi teadus. ${ }^{5}$ Seetõttu on mõistetav, et just tema esines eespool nimetatud kompartei 1944. aasta detsembripleenumil programmilise sõnavõtuga ajaloo ümberhindamise küsimustes, pannes paika edasised tegevussuunadki: "Üks võimsamaid relvi võitluses kodanlise natsionalismi vastu on kindlasti Eesti ajalugu. On vaja, et meie seda võtaksime kasutamisele palju ulatuslikumalt, kui meie seda seni oleme teinud. Just meie õieti, marksistlikult

\footnotetext{
2 Teet Veispak, “Ajalooteadusest kui venestuse ideoloogia kandjast (1944-1952)", Looming, 9 (1990), 120-126; Jaan Undusk, "Retooriline sund Eesti nõukogude ajalookirjutuses", Võim ja kultuur, koost Arvo Krikmann, Sirje Olesk (Tartu: Eesti Kirjandusmuuseum, 2003), 41-68; Olaf Kuuli, Eesti ajaloo kirjutamisest Stalini ja Hruštšovi ajal (Tallinn: Tallinna Raamatutrükikoda, 2008); Ants Viires, "Eesti ajalugu stalinistlikus haardes", Tuna, 1 2003, 32-47.

3 Helen Lausma-Saar, Ajalooteadus Nõukogude Eestis 1944-1952, magistritöö, juhendaja Priit Raudkivi (Tallinna Ülikool, 2012).

4 Jüri Kivimäe, Rektor Hans Kruus (Tallinn: Aasta Raamat, 2017).

5 Vt põhjalikumalt H. Kruusi tegevuse kohta aastatel 1944-50 Jüri Kivimäe monograafiast: Kivimäe, Rektor Hans Kruus, 148-165.
} 
valgustatud ajalugu võimaldab meil eriti veenvalt, kõige intiimsemalt lähineda meie inimestele, võimaldab suure efektiivsusega hajutada nendes natsionalistlikke eelarvamusi ja kummutada nende eelarvamuste olulisi põhialuseid."6

Ühtlasi fikseeris Kruus ka esmased uurimistöö sihid ajaloolastele. Ta leidis, et uue režiimi ülesehituse "seisukohalt tõuseb meil eriti vajalikuks ja esmajärguliseks uurimis- ja käsitlusobjektiks kodanlise Eesti ja saksa okupatsiooni ajastud, mis seni olnud meile kõige vähem ajalooliselt uuritud ja tuntud". Ta oli veendunud, et nende "perioodide lähem tundmaõppimine avastab meile suurima, võiks öelda koguni hämmastava selgusega eesti kodanlise natsionalismi klassiolemuse, tema kliki-ideoloogiaks mandumise ja rahvareetmise krahhi hilpudeks varisemise teel". Kruus mõistis suurepäraselt, et iseseisvusaja pärandi marksistlikelt positsioonidelt hindamine on hädavajalik kasvatamaks "uut inimest, kes oleks vaba eelmise, kodanlise korra, eriti aga fašismi poolt sisendatud ja levitatud mürgiste eelarvamuste köidikuist". Kruus tõdes, et "Nõukogude Eesti suures ülesehitustöö programmis seisab esikohaliste küsimuste hulgas meie inimese, kogu meie ühiskonna poliitiline, ideoloogiline, vaimne kujundamine"?

Kruusi jaoks oli võitlus kodanliku natsionalismi vastu "puhastusaktsiooni ilmega": "Aastal 1944 peame meiegi asuma küürimistööle. Meie küürimine aga pole sümboolne, vaid vägagi praktiline toiming. [...] Meie ees seisab ülesanne puhtaks küürida meie ühiskond vaimselt fašismi ja kodanlise natsionalismi saastast. Seda peame tegema selleks, et meie inimeste teadvuses pääseks võidule tõeline nõukogulik vaimsus, mis on vajalik, et kujundada tõelikku nõukogulikku sotsialistlikku ühiskonda, mis viiks võidule ka Eesti meie Partei ja meie suure võitluse kõrged ideaalid."

Ajaloo teema jõuline tõstatamine EK(b)P KK 1944. aasta detsembripleenumil ei tuginenud Moskvast saadud korraldustele, vaid oli suuresti Kruusi initsiatiiv, millel oli kindlasti parteijuhi N. Karotamme heakskiit. Tähelepanuväärne on siinkohal tõsiasi, et just Eesti vabariigi perioodi uurimist peeti üheks esmatähtsaks ülesandeks ajaloo uurimise vallas. Eesti omariikluse aja põlustamise vältimise üheks põhjuseks oli soov teha

6 Rahvusarhiiv [edaspidi RA], ERAF.1.104.107, 1.34: ENSV välisasjade rahvakomissari H. Kruusi sõnavõtt EK(b)P KK pleenumil o2.12.1944. Vt. selle kõne publikatsiooni: Tõnu Tannberg. “"Aastal 1944 peame meiegi asuma küürimistööle”. Hans Kruusi kõne EK(b) P KK pleenumil 2. detsembril 1944", Tuna, 4 (2018), 104-108.

7 RA, ERAF.1.104.107, 1. 32, 34: ENSV välisasjade rahvakomissari H. Kruusi sõnavõtt EK(b)P KK pleenumil 02.12.1944.

8 RA, ERAF.1.104.107, 1. 36-37. ENSV välisasjade rahvakomissari H. Kruusi sõnavõtt EK(b)P KK pleenumil 02.12.1944. 
sovetirežiim ühiskonna jaoks võimalikult vastuvõetavaks. Seetõttu pöörasid Karotamm ja tema lähikondlased suurt tähelepanu Eesti vabariigis tegutsenud kirjanike, teadlaste jt ühiskonnas tuntud inimeste vähemal või suuremal määral kaasamisele sovetiseerimisprotsessi läbiviimisesse. Igal juhul oli kasulik näidata nende seotust uue võimuga. ${ }^{9}$

Nõukogude režiimi algusaastate üheks esmaseks ülesandeks oli tõepoolest erinevate ühiskonnakihtide, sealhulgas mõistagi ka haritlaskonna kaasamine poliitilise võimu teenistusse ning ühtlasi kontrolli kehtestamine ühiskonna vaimuelu üle. Nende eesmärkide realiseerimiseks kasutati mitmeid abinõusid ja vahendeid. Neid eesmärke pidid aitama realiseerida ka Eesti taasokupeerimise järel kahel korral kokkukutsutud nn intelligentsi kongressid, milledest esimene toimus 1945. aasta jaanuaris ja teine kolm aastat hiljem - 1948. aasta märtsis. ${ }^{10}$

Intelligentsi I kongressi kokkukutsumist arutati EK(b)P KK büroos juba 1944. aasta detsembris ning otsustati, et "poliitilise töö parandamiseks haritlaskonna seas" ning nende "kaasatõmbamiseks aktiivseks osavõtuks poliitilisest, majanduslikus ja kultuurhariduslikus tööst" on vaja järgmise aasta jaanuaris korraldada haritlaskonna vabariiklik koosolek. ${ }^{11}$ EK(b)P KK propaganda- ja agitatsiooniosakonna ülesandeks jäi vabariikliku kongressi ettevalmistamise käigus korraldada haritlaste nõupidamisi maakondades ja linnades. Kongressi otsene ettevalmistamine pandi vastava komisjoni õlule, mida juhatas EK(b)P KK sekretär propaganda- ja agitatsiooni alal Eduard Päll. Teemakohased artiklid ilmusid nii maakondlikes kui ka liiduvabariiklikes ajalehtedes.

Eesti NSV intelligentsi I kongress toimus 28.-29. jaanuaril 1945. aastal Tallinnas ja sellest võttis osa üle 700 haritlaskonna esindaja. Kongressi avas Eesti NSV hariduse rahvakomissar Jüri Nuut, kuid peaesinejaks oli EK(b)P KK esimene sekretär Nikolai Karotamm, kes oma programmilises kõnes visandas ülesanded, mille lahendamist nõukogude võim haritlaskonnalt ootas. Kongressi lõpus võeti vastu läkitus Nõukogude Eesti intelligentsile. ${ }^{12}$ Pole kahtlust, et intelligentsi kongressi kokkukutsumine pidi mobiliseerima haritlaskonda usinasti uut võimu teenima. Kirjanik Jaan Kärneri

\footnotetext{
9 Vt näiteks Friedebert Tuglase juhtumit: Tõnu Tannberg, ““'̃ieti oli ju “Elu tsitadellis” see viiekopikaline minu hukkamisloos...”", Looming, 4 (2018), 536-537.

10 Intelligentsi kongresside kohta vt lähemalt Tiiu Kreegipuu, Nõukogude Liidu kultuuripoliitika ja selle rakendamine Eesti NSV ajakirjanduse ja kirjanduse juhtimisel 1944-49, lõputöö, juhendaja Tõnu Tannberg (Tartu ülikool, Eesti ajaloo õppetool, 2001), 37-43.

11 RA, ERAF.1.4.123, 1. 74: EK(b)P KK Büroo koosoleku protokoll nr. 85, 10.-14.12.1944.

12 Kongressi sõnavõtud ilmusid ka eraldi raamatuna: Eesti NSV intelligentsi esimene kongress (Tallinn: Poliitiline Kirjandus, 1945).
} 
sõnul oli intelligentsi kongressil "tugev mõju Eesti intelligentsi poliitilise mõtlemise aktiviseerimisel" ning ta leidis, et see andis haritlastele "määratu tõuke oma maailmavaate ümberkujundamiseks". ${ }^{13}$

Samal kongressil ütles Hans Kruus: "Meie intelligents on suuremas osas üles kasvanud kodanliku Eesti perioodil, on lühikese ajaga läbi teinud ja läbi elanud kolm suurt murrangut: nõukoguliku korra tuleku 1940. aastal, saksa fašistliku okupatsiooni, mis algas järgmisel aastal, ja lõpuks kodumaa vabastuse võidurikka Punaarmee poolt 1944.a."14 Ta rõhutas vajadust "kodanliku Eesti ajastu" poolt jäetud "väärarvamuste jäänused" ühiskonnast kõrvalda, kuid see ei tähendanud omariikluse aja heitmist ajaloo prügikasti. Ajalooteaduse ülesandeks oli anda "kodanlikule Eesti riigile" nõukogulik sisu.

Ajalooteaduse nõukogustamise üheks esmaseks praktiliseks ülesandeks sai Eesti ajaloo marksistliku periodiseeringu väljatöötamine. Selle ülesande tähtsust rõhutas juba esimesel punasel aastal Kruus: "Meie ajaloo periodiseerimist hakkab nüüd kindlailmeliselt juhtima ühiskondlikmajanduslikkude formatsioonide tõelise muutumise tundmaõppimine."15 Tollal ajaloo periodiseerimise küsimustega sisuliselt ei jõutud tegeleda, kuid Eesti taasokupeerimise järel tõusis see küsimus uuesti päevakorda.

Nõukoguliku periodiseerimisskeemi koostamine oli uuele režiimile vajalik mitmel põhjusel. Seda oli esmalt vaja loomulikult ajalooteaduse üldiseks nõukogustamiseks, ülikoolis õppetöö läbiviimiseks, kuid veelgi enam Eesti ajaloo üldkäsitluse koostamisel. 1945. aasta alguses toimunud Eesti NSV intelligentsi I kongressil rõhutas Nikolai Karotamm: “Tuleb anda Eestimaa ajaloo õige periodiseerimine" ${ }^{16}$ Karotamm pidas seda küsimust tõesti oluliseks. Paar aastat hiljem avaldas ta ise artikli EKP ajaloo periodiseerimisest ning jagas üldisi suuniseid kogu Eesti ajaloo periodiseerimiseks. ${ }^{17}$

Ajaloolastest tegeles periodiseerimise küsimustega kõige rohkem Artur Vassar, kes pidas Tartu Riiklikus Ülikoolis 1948. aasta juunis toimunud teaduslikul sessioonil sel teemal programmilise ettekande. ${ }^{18}$ Vassar tõdes

13 Jaan Kärner, "Nõukogude Eesti intelligentsi esimene kongress", Looming, 2 (1945), 153. 1948. aastal võiski Eduard Päll Eesti NSV teisel intelligentsi kongressil tõdeda, et haritlaskond on n-ö siiralt asunud bolševike partei lipu alla.

14 Eesti NSV intelligentsi esimene kongress, 38.

15 Hans Kruus, "Uue ajajärgu alguses", Ajaloo Ajakiri, 5 (1941), 5.

16 Nikolai Karotamm, "Tuleb anda Eestimaa ajaloo õige periodiseerimine”, Uut elu ehitades: kõnesid ja kirjutusi 1945./1946. aaastal (Tallinn: Poliitiline Kirjandus, 1946), 38.

17 Nikolai Karotamm, "Eestimaa Kommunistliku (bolševike) Partei ajaloo küsimusi", Eesti Bolševik, $\mathrm{nr}$ 15, 1947, 19.

18 RA, ERA.R-2343.3.40: A. Vassar. Eesti ajaloo periodiseerimisest, 1947. 
oma ettekandes: "Eesti ajaloo periodiseerimine tuli ajaloolastel teostada vähemalt esialgseltki - ühenduses Eesti ajaloo ülikooli kursuse programmi ja Eesti ajaloo õpiku käsikirja koostamisega. Seega on Eesti ajaloo periodiseerimises katseid tehtud juba ligi 3 aastat, millest prof $\mathrm{H}$. Kruusi juhtimisel ja kõige aktiivsemal kaastööl on sel või teisel viisil osa võtnud enamik meie ajaloolasi." ${ }^{\prime 19}$ Tõepoolest, Hans Kruus on ka ise hiljem rõhutanud, et pidas juba 1945. aastal Tartu ülikoolis kuuetunnilise ettekande periodiseerimise teemal. ${ }^{20}$

Edaspidi aga vedas nõukoguliku periodiseerimisskeemi väljatöötamist Kruusi tollaseid lähimaid abilisi - Artur Vassar. Tema sai oma töö valmis 1947. aasta suvel ja esitas selle ajakirja Eesti Bolševik toimetusele. Artikkel jäi siiski avaldamata, kuna Vassar soovis selle teksti kasutada 1948. aasta Eesti NSV Teaduste Akadeemia teadusliku sessiooni ettekandena. Aga oli teisigi tegureid, mis selle artikli avaldamist takistasid. Nimelt selgus, et Vassara tekstile lisaks oli Eesti Bolševiku toimetusele laekunud konkureeriv periodiseerimise kava, mille autoriteks olid EK(b)P KK vabariikliku parteikooli ajaloo kateedri juhataja Abe Liebman ja tollal Moskvas ÜK(b)P KK kõrgemas parteikoolis õppiv Gustav Naan. H. Kruusi jaoks tuli konkureeriva kava väljatöötamine üllatusena. EK(b)P KK seminaril tõdes ta, et Liebmani-Naani kava oli välja töötatud omaette, kusjuures see "ühtus Vassari kokkuvõttega, oli aga kriitilises osas teravam". ${ }^{21}$

Mõlemad versioonid arutati läbi tollase EK(b)P KK propagandasekretäri Ivan Käbini juures, ühtlustati ning avaldati 1948. aasta septembri Eesti Bolševiku numbris. ${ }^{22}$ Artikkel ilmus ilma autorite nimedeta, kuid saatetekstis oli öeldud, et tegemist oli H. Kruusi, A. Vassara, A. Liebmani ja G. Naani kollektiivse tööga. Aluseks oli siiski Vassara skeem, mida täiendati Naani ja Liebmani omaga. 1948. aasta juulis tõdes Naan: "Ühendamine oli tehtud päris hästi, veidi ainult liiga rahu säilitamise vaimus." ${ }^{23}$ Sellegipoolest ei läinud tekst veel kohe käiku, kuna asjaosalised ei olnud ajakirja toimetuses tehtud kahe teksti ühtlustamisega rahul. Sellest annab tunnistust Hilda Moosbergi 1948. aasta suvine kiri Eesti NSV TA ajaloo instituudi

19 RA, ERA.R-2343.3.40, 1. 3: A. Vassara ettekande tekst "Eesti ajaloo periodiseerimisest", 14.06.1948.

20 Teaduste Akadeemia arhiiv [edaspidi TA arhiiv], 55.1.99, 1. 1: H. Kruusi sõnavõtt EK(b)P KK seminaril, 23.09.1948.

21 TA arhiiv, 55.1.99, 1. 1: H. Kruusi sõnavõtt EK(b)P KK seminaril, 23.09.1948.

22 "Eesti ajaloo periodiseerimisest", Eesti Bolševik, nr 17, 1948, 39-58.

23 Vt lähemalt G. Naani ja A. Liebmani koostööst periodiseerimiskeemi väljatöötamisel: Helen Lausma-Saar, ““Enne diskussiooni võta $100 \mathrm{~g}\left(40^{\circ}-80^{\circ}\right)$ !” Gustav Naani kolm kirja Abe Liebmanile”, Tuna, 4 (2012), 100-104. 
direktorile Richard Kleisile: "Uudistest oleks teatada, et "Eesti Bolševiku" mehed olid A. Vassari artikli "periodiseerimisest" mehhaaniliselt liitnud Naani ja Liebmani omaga, mina ja Vassar ei võinud sellega nõustuda, pidasin lahingu Aisenstadtiga, ${ }^{24}$ lubasid lõpuks mitte avaldada enne kui pidada üks ühine koosolek ära." ${ }^{25}$ Ilmselt pärast seda veel teksti ühtlustati, kuid juba septembri alguses anti Eesti Bolševiku number ladumisele. ${ }^{26}$

Nõukoguliku periodiseerimisskeemi avaldamine 1948. aastal oli oluliseks tähiseks ajalooteaduse nõukogustamisel, kuna esmakordselt toodi avalikkusse ette ühiskondlik-majanduslikele formatsioonidele tuginevad Eesti ajaloo põhiperioodid. Kuigi periodiseerimisskeemi hiljem täpsustati ja laiendati, jäi see aluseks edasistele käsitlustele ja andis pikkadeks aastateks raamistiku ajaloo uurimisele Eesti NSV-s.

Periodiseerimise problemaatika ei olnud aktuaalseks küsimuseks mitte ainult Eestis, vaid ka üleliidulisel tasandil ja teistes liiduvabariikides. Üleliidulise periodiseerimise-alase diskussiooni vahekokkuvõte tehti 1951. aastal. ${ }^{27}$ Artur Vassar ja Hilda Moosberg avaldasid 1950. aastal Moskvas eraldi artikli Eesti NSV ajaloo periodiseerimise kohta. ${ }^{28}$ Kohalikul tasandil saavutati teatud konsensus 1952. aastal, kui kiirkorras jõudis trükiküpseks Gustav Naani, Viktor Maamäe ja Artur Vassara eestvedamisel üheköitelise Eesti NSV ajaloo käsikiri. Tollal paikapandud marksistlik periodiseerimisskeem, mis sai ühtlasi aluseks ka kolmeköitelisele Eesti NSV ajaloole, jäi sisuliselt püsima kuni nõukogude ajal lõpuni. ${ }^{29}$

Nõukoguliku periodiseerimisskeemi väljatöötamine oli oluline ka “kodanliku Eesti riigi” uurimist Eesti NSV-s silmas pidades. Gustav Naan rõhutas oma algsetes märkmetes: "Ajaloo periodiseerimise skeemis kajastub ajaloolase maailmavaade. Periodiseerimise ühe või teise skeemi valimisega ajaloolane rõhutab teatavate tegurite osatähtsust ajalooprotsessis, tõstab esile teatavaid sündmusi, muudatusi, ühiskondlikke liikumisi, mis tema

24 Tollane ajakirja Eesti Bolševik peatoimetaja Leo Aisenstadt.

25 Tartu Ülikooli raamatukogu käsikirjade ja haruldaste raamatute osakond [edaspidi TÜR KHO], f. 9o, s. 222, 1. 8: H. Moosberg R. Kleisile, 19.07.1948.

26 Siinkohal ei käsitleta I. Käbini rolli ja laiemalt Naan-Liebman versus Kruus-Vassar konkurentsi nõukoguliku periodiseerimiskeemi väljatöötamisel.

27 "Ob itogakh diskussii o periodizatsii istorii SSSR", Voprosy istorii, 3 (1951), 53-6o.

28 G. Mosberg, A. Vassar, "Osnovnȳe voprosȳ periodizatsii istorii Ėstonskoŭ SSR", Voprosy istorii, 10 (1950), 60-71.

29 Eesti NSV ajaloo periodiseerimise küsimus oli eraldi päevakorras Eesti NSV Teaduste Akadeemia ühiskonnateaduste osakonna sessioonil 1952. aasta suvel, kus olid kohal ka NSV Liidu juhtivad ajaloolased. Sellel sessioonil peetud Harri Moora, Artur Vassara, Joosep Saadi ja Viktor Maamäe ettekanded avaldati hiljem ka eraldi raamatuna (Eesti NSV ajaloo periodiseerimisest (Tallinn: Eesti Riiklik Kirjastus, 1954)). 
arvates tingivad teisi sündmusi, muudatusi ja ühiskondlikke liikumisi."30 Omariikluse sündi pidas G. Naan mõistagi “suureks sammuks tagasi Eesti ajaloos" ning selle perioodi sisemist arengut ta periodiseerida ei püüdnud, tõdedes, et "on kodanlik iseseisvus eesti rahva ajaloos ainult võiks ütelda episood, ent kuidagi mitte ajaloolise arengu kroon" ${ }^{31}$

A. Vassar nimetas oma 1948. aasta ettekandes aastaid 1920-40 "kodanluse diktatuuri ajajärguks Eestis” ning tõi välja ka alaperioodid: töölisliikumise tõusperiood (1920-24), kodanluse võimu ajutine stabiliseerumine (1925-29), majanduskriisi aeg (1929-33) ning fašistliku diktatuuri aeg (193440). ${ }^{32}$ A. Liebman ja G. Naan nimetasid samuti oma ühises periodiseerimiskavas (kus põhitöö tegi ära Liebman) Eesti omariikluse aega "kodanluse diktatuuri ajajärguks" ning tõid välja Vassaraga samad alaperioodid (väikeste erisustega), mis on eelkõige EKP ajalugu silmas pidades detailsemalt lahti kirjutatud. ${ }^{33}$

Ajakirjas Eesti Bolševik ilmunud ühtlustatud versioonis on Eesti vabariigi osas aluseks võetud A. Liebmani ja G. Naani tekst, mida on pisut kohendatud. Loomulikult ei olnud Eesti vabariigi aja jagamine neljaks alaperioodiks mingi originaalne lahendus, vaid ÜK(b)P lühikursusest ülevõetud skeem, millest lähtuti toonases nõukogulikus ajalooteaduses. Hoopis olulisem on aga nendele alaperioodidele antud sisu ja märksõnad, mis määrasid järgnevateks aastateks ära omariikluse perioodi käsitlemise rõhuasetused ning tonaalsuse ajalookirjanduses. Lähtuti seisukohast, et tõeliselt "marksistliku periodiseeringu loomise tähtsaimaks eeltingimuseks on parteiline seisukoht ajalookäsituses" ${ }^{34}$

1948. aastal sõnastatud omariikluse perioodi põhisisu ja murrangumomendid seisnesid lühidalt järgmises. Esiplaanile tõsteti töölisliikumine ja selle "kangelaslik" väljaastumine 1924. aasta detsembris. Järgnenud ajutise ühiskondliku stabiilsuse aastad saavutas "müüdav kodanlus sõltuvuse suurendamisega väliskapitalist”. Sellele perioodile järgnes majandusliku ja poliitilise kriisi ajajärk, mis tõi töörahavale kaasa "enneolematuid kannatusi" ja päädis "kodanliku demokraatia” kriisiga, millest "eesti kodanlus nägi väljapääsu ainult üleminekus "fašistlikele valitsemismeetodeile”. Ka teisele sõlmaastale - 1934 - antud hinnang oli edasist ajaloouurimist silmas pidades teedrajava tähtsusega: "Eesti hitlerlased - vapsid - algatasid

30 TÜR KHO, f. 9o, s. 537, 1. 1: G. Naan. Märkmeid Eesti ajaloo periodiseerimisest.

31 TÜR KHO, f. 9o, s. 537, 1. 8: G. Naan. Märkmeid Eesti ajaloo periodiseerimisest.

32 RA, ERA.R-2343.3.40, 1. 3: A. Vassara ettekande tekst "Eesti ajaloo periodiseerimisest", 14.06.1948.

33 RA, ERA.R-2343.3.237: A. Liebman, G. Naan. Eesti ajaloo periodiseerimise probleeme.

34 "Eesti ajaloo periodiseerimisest", Eesti Bolševik, nr 17 (1948), 39. 
liikumise fašistliku põhiseaduse läbiviimiseks. Eesti kodanluse teine rühm eesotsas Pätsi-Laidoneriga, kasutades ära seda liikumist, pani 1934. a märtsikuus toime riigipöörde ning kehtestas Eestis fašistliku diktatuuri.” Pärast 1934. aastat aga "valitsev klikk tüüris fašistliku diktatuuri perioodil järjest rohkem hitlerliku Saksamaa sõiduvette ja muutus tema tööriistaks Nõukogude Liidu vastase sõja ettevalmistamises". Töörahvas küll võitles "fašismi ja reaktsiooni vastu, vabaduse ja rahu eest", kuid alles "1940. aasta juunipöördega vabastas eesti rahvas oma maa alandavast sõltuvusest imperialistlikest suurriikidest ja asendas näilise iseseisvuse tõelise iseseisvusega". ${ }^{35}$

Punavõimu eesmärgiks oli loomulikult ka teaduskorralduse nõukogustamine. Selle protsessi keskseks ettevõtmiseks sai Eesti NSV Teaduste Akadeemia loomine 1946. aastal. ${ }^{36}$ Siingi oli võtmefiguuriks Hans Kruus, kellest sai akadeemia esimene president ning NSV Liidu TA korrespondentliige. Teaduste Akadeemia allasutustena hakkasid tegutsema erinevad teadusinstituudid. Nii hakati ka Eesti NSV-s juurutama nõukogulikku teadussüsteemi, kus Teaduste Akadeemia süsteemi kuuluvatel instituutidel oli juhtroll teadustöö edendamisel erinevalt kõrgkoolidest, kellelt oodati eelkõige teaduskaadri ettevalmistamist ja mitte esmaülesandena uurimistööle panustamist. Eesti NSV TA ajaloo instituudist (direktoriks Richard Kleis) sai nõukogulikus teadussüsteemis ajalooteaduse (koos arheoloogia ja kunstiajalooga) keskne uurimisasutus.

Teaduste Akadeemia tööle rakendamise ajal pandi paika ka erinevate uurimisinstituutide pikemaajalised uurimisplaanid. ${ }^{37}$ Ajastule omaselt pidi teadustegevuse planeerimine tuginema viisaastaku tsüklile. Selle töö käigus valmis ajaloo instituudi perspektiivne tööplaan aastateks 1946-50, mis haaras endasse Eesti ajaloo sektori, arheoloogia sektori, kunstiajaloo sektori ja Suure Isamaasõja ajaloo kabineti uurimiskavad. ${ }^{38}$

Meie teema seisukohast, silmas pidades sõjaeelse Eesti vabariigi perioodi uurimist, on järgnevalt tähelepanu pööratud just Eesti ajaloo sektori (juhatajaks Artur Vassar) uurimistöö plaanile. Kõnesolev plaan nägi sektori

35 "Eesti ajaloo periodiseerimisest", Eesti Bolševik, nr 17 (1948), 56-57.

36 Vt selle kohta lähemalt: Ken Kalling, Erki Tammiksaar, Eesti Teaduste Akadeemia: ajalugu, arenguid ja järeldusi (Tallinn: Eesti Teaduste Akadeemia, 2008).

37 H. Kruus tõdes: "Nõukogude teaduse esimeseks põhimiseks iseärasuseks on uurimistöö teostamine plaani alusel. Selle plaani temaatika suhtes on kehtiv nõue, et ta oleks kõige tihedamas, lausa orgaanilises seoses nõukogude riigi, ühiskonna ja rahvamajanduse eluliste vajadustega ning sotsialistliku kultuuri edasiviimise huvidega (RA, ERA.R-2343.3.31, l. 1: H. Kruusi artikli käsikiri "Meie põhilistest tööülesannetest ajaloo, keele, kirjanduse ja folkloori alal").

38 RA, ERA.R-2343.2.7; Eesti NSV TA Ajaloo Instituudi teadusliku uurimistöö plaan 1946-1950 (koos muudatustega ja lühiaruandega plaani täitmise kohta). 
esmaste ülesannetena ette marksistlike ülevaateteoste koostamist Eesti ajaloost, kus tulnuks anda ka terviklik ülevaade Eesti vabariigi perioodist.

Õigupoolest oli tollal esmaseks sihiks kirjutada kiirkorras valmis Eesti ajaloo õpik. Seda küsimust arutati juba 1945. aasta septembris, ${ }^{39}$ mil veel Eesti NSV juhtkonnas ekslikult eeldati, et üldhariduskoolides hakatakse õpetama eraldi ainena Eesti ajalugu. Seda aga ei juhtunud ning õpiku algne, kiirkorras valminud tekst (kuni Põhjasõjani) jäi käsikirja.

Kuid õpiku ideed maha ei maetud ning see võeti üle ajaloo instituudi töökavadesse. Suur nõupidamine õpiku koostamise asjus toimus Tartus 11. novembril 1946. aastal. ${ }^{40}$ Selle teose eesmärgiks oli "marksistliku-leninliku teooria seisukohtadest lähtudes" anda "populaarne ülevaade Eesti ajaloost". Lisaks rõhutati kavandatava õpiku annotatsioonis, et raamat on "määratud esialgseks orienteerumiseks Eesti ajaloos ja rahuldaks sellisena laiade masside vajadusi" ning ühtlasi oleks väljaanne "suunava tähtsusega Eesti ajaloo õpetamisel koolides". ${ }^{41}$ Esialgsete kavade kohaselt pidi õpiku käsikiri (u 12 autoripoognat) H. Kruusi eestvedamisel valmis saama juba 1947. aasta lõpuks. Õpiku tegemine teisenes mõne aja möödudes hoopis kavaks välja anda kaheköiteline "Lühike Eesti ajalugu", mille I köite käsikiri valmis 1948. aastaks. Käsikirja teksti arutati (sh ka EK(b)P KK seminaril) ja täiendati korduvalt ning 1949. aasta lõpuks oli see põhimõtteliselt trükivalmis.

Õpikuga paralleelselt aga tuli alustada uue kolmeköitelise Eesti ajaloo üldkäsitluse koostamist. Siinkohal on sobilik pikemalt tsiteerida kavandatava teose annotatsiooni: "Teose ülesandeks on anda üksikasjalisem ning süvendatud käsitlus Eesti ajaloo käigust vanimaist aegadest kuni nüüdisajani. Teos on hädavajalik, sest senised kodanlikust perioodist pärinevad Eesti ajaloo üldkäsitlused kannatavad kodanliku ajalooteaduse üldiste puuduste all. Esmakordselt tuleb planeeritavas teoses Eesti ajalooline minevik vaatlusele ning hindamisele marksistlik-leninliku teooria vaatekohtadelt. Teos on tarvilik õppe- ja käsiraamatuna Eesti NSV kõrgemais õppeasutusis ja oma üldarusaadava käsitlusviisi tõttu sobiv arendama Eesti ajaloo sügavamat tundmist ning mõistmist ka laialdasis ringkonnis." ${ }^{\prime 2}$ Nõukoguliku üldkäsitluse esimese köite käsikiri pidi valmis saama 1948. aastal, teine köide 1950. aastal ning kolmas 1951. aastal. Väljaande, mille kogumahuks kavandati u 60 trükipoognat, vastutavaks toimetajaks oli samuti Hans Kruus.

\footnotetext{
39 Kuuli, Eesti ajaloo kirjutamisest Stalini ja Hruštšovi ajal, 13.

40 TÜR KHO, f. 90, s. 23, 1. 3: R. Kleisi päeviku sissekanne 11.11.1946.

41 RA, ERA.R-2343.2.7: Eesti NSV TA Ajaloo Instituudi teadusliku uurimistöö plaan 1946-1950 (koos muudatustega ja lühiaruandega plaani täitmise kohta).

42 Ibid.
} 
Mõlemat ülevaateteost - nii õpikut kui ka üldkäsitlust - hakati ajaloo instituudis optimistlikult ette valmistama, kuid üsna ruttu innukus rauges ning esialgselt kavandatud moel nende ülevaateteoste koostamine äpardus. ${ }^{43}$ Kuna alustati vanematest perioodidest, siis 20. sajandi teemadeni nende "projektide" raames ei jõutudki.

Ülevaateteoste kõrval oli Eesti vabariigi perioodi uurimine ajaloo instituudi esialgsetes uurimisplaanides esindatud üllatavalt suure mahuga. Kokku oli Eesti ajaloo sektori töökavades 14 teemat ja nendest koguni neli olid orienteeritud sõjaeelse Eesti vabariigi uurimisele (lisaks õpikule ja kolmeköitelisele üldkäsitlusele).

Ajastule omaseks teemaks oli "Poliitilised kohtuprotsessid kommunistide vastu kodanlikus Eestis aastail 1919-1924" (u 10 trükipoognat), millega hakkas tegelema sõjajärgsel ajal Eestisse toodud ajalookandidaat Aleksandr Gronski. Tema uurimus pidi esialgse plaani järgi valmis saama 1948. aastal ning töö sihiks seati "uurimuslik ülevaade neist kohtuprotsessidest, mida võimulepääsnud kodanlus organiseeris Eesti kodanliku riigi esimesil aastail kohaliku töötava rahva silmapaistvamate esindajate vastu kommunistliku liikumise mahasurumise eesmärgil". Lisaks oli kavas Viktor Kingisepa eluloo (u 20 trükipoognat) koostamine, kuid selle ülesande täitmiseks ei olnud instituudi uurimisplaani kinnitamise ajaks veel autorit paika pandud. Mõni aeg hiljem hakkas ka V. Kingisepa kohta materjali koguma A. Gronski.

Hoopis olulisemad olid aga kaks järgmist uurimisteemat. H. Kruus kavatses kirjutada raamatu "Eesti kodanlik riik 1918-1920" (u 12 trükipoognat), mis pidi valmis saama juba 1947. aastal. See teema leiti olevat eriti "aktuaalne eesti ühiskonna poliitilise kasvatuse ja temast kodanlikust perioodist pärinevate eelarvamuste ning väärvaadete väljajuurimise seisukohalt" ${ }^{44}$ Kruusi kavandatav monograafia pidi andma "üldise populaarset laadi ülevaate Eesti kodanliku riigi klassiolemusest, tema majanduslikest aluseist, temas arenenud klikkidevahelisest võitlusest, välispoliitikast" ${ }^{45}$

Teine võtmeteema aga oli pealkirjastatud "Kodanliku Eesti välispoliitika aastail 1934-1940" (u 15 trükipoognat) ning selle täitjaks oli ette nähtud Feliks Roose, kes oli sõjaaastatel Nõukogude tagalas H. Kruusi üks lähimaid abilisi. Tähelepanuväärne on tõsiasi, et Roose oli kuni 1947. aastani

43 Vt Eesti ajaloo õpiku ja üldkäsitluste koostamise kohta lähemalt Kuuli, Eesti ajaloo kirjutamisest Stalini ja Hruštšovi ajal, 21-27.

44 RA, ERA.R-2343.2.7: Eesti NSV TA Ajaloo Instituudi teadusliku uurimistöö plaan 1946-1950 (koos muudatustega ja lühiaruandega plaani täitmise kohta).

45 Ibid. 
töötanud Kruusi alluvuses Eesti NSV välisministeeriumis ning seejärel suunati ta ajaloo instituuti toimetus-kirjastusnõukogu vastutavaks sekretäriks. ${ }^{46}$ Roose uurimus pidi valmima 1949. aastal.

Sellegi teema kirjeldus väärib pikemat tsiteerimist: "Hoolimata oma maa-ala väiksusest ja samuti oma väga piiratud sõjalisest potentsiaalist kujunes Eesti kodanlik riik, tänu peamiselt oma maa geograafilisele asendile ja tema ümber ristelnud rahvusvahelistele huvidele välispoliitiliselt õige silmapaistvaks nähtuseks. Kapitalistliku maailma ääremaana ja platsdarmina Nõukogude Liidu vastu ja oma klassiolemuse tõttu viimasele vaenulik, majanduslikult väliskapitali tugeva mõju ja surve all, kujunes kodanlik Eesti õige pingeliste rahvusvaheliste intriigide objektiks. Selles osas sai tema ilma eriti selgejooneliseks K. Pätsi diktatuuri perioodil 1934-1940. Samal ajal langes selle kodanliku väikeriigi välispoliitika ikka enam ja enam fašistliku Saksamaa mõju alla. Selle välispoliitika lähem uurimine mainitud ajajärgul annab olulise panuse rahvusvahelise olukorra lähemaks tundmaõppimiseks Teise Imperialistliku Maailmasõja lähemail eelaastail." ${ }^{37}$

Enamik nendest kavadest jäid siiski teostamata. Kõige "edukamalt" sai oma ülesandega hakkama A. Gronski, kes esitas oma teema kohta erineva pikkusega käsikirju, mille sisuline kvaliteet jättis siiski soovida. ${ }^{48} \mathrm{~V}$. Kingisepa eluloo uurimine anti peagi üle EK(b)P KK partei ajaloo instituudile. H. Kruusi kavandatava monograafia kohta tõdeti instituudi 1947. aasta aruandes, et see on põhiosas valmis. Siinkohal on siiski tegemist ilmse eksitusega, kuna käsikirja tervikuna kunagi instituudis arutlusele ei võetud. ${ }^{49}$ Veelgi enam, 1948. aastal muutis Kruus oma uurimistöö fookust ning tema uueks teemaks kinnitati "Kodanliku Eesti välispoliitika 1918-1940". Kuna see kattis ka F. Roose senise teema, siis viimane kustutati üldse sektori teadustöö plaanist.

1949. aasta kontrolliti EK(b)P KK nõudel Eesti NSV TA ajaloo instituudi ja sealhulgas Eesti ajaloo sektori tegevust ja teadustööd mitu korda. Eesti NSV TA ajaloo instituudi üle pidi parteilist järelevalvet teostama

46 F. Roose oli sunnitud Eesti NSV välisministeeriumist lahkuma, kuna ta heideti 1947. aastal komparteist välja. Ei ole kahtlust, et ta sai koha ajaloo instituudis H. Kruusi abil. Vt Mart Orava koostatud F. Roose elulugu ajakirja Akadeemia 2012. aasta esimeses numbris (lk 70-74).

47 RA, ERA.R-2343.2.7: Eesti NSV TA Ajaloo Instituudi teadusliku uurimistöö plaan 1946-1950 (koos muudatustega ja lühiaruandega plaani täitmise kohta).

48 A. Gronski tekste arutati korduvalt ajaloo instituudi Eesti ajaloo sektori koosolekutel.

49 H. Kruus avaldas ajakirjanduses mitu artiklit "kodanliku Eesti" sisepoliitika teemadel. Eriti väärib äramärkimist tema pikema käsitlus Eesti vabariigi viimase põhiseaduse loomises, mis ilmus ajalehes Rahva Hääl 1946. aasta jaanuaris. 
EK(b)P Tartu linnakomitee, kes pärast märtsiküüditamise läbiviimist võttiski instituudi tegevuse luubi alla. Juba 1949. aasta aprillis pidas EK(b)P KK Tartu linnakomitee sekretär Valdar Leede vajalikuks kontrollida TA ajaloo instituudi tegevust, sest teose "Lühike Eesti ajalugu" esimene köide polnud veel ilmunud, töö teise köitega ei edenenud ning arheoloogide ja kunstiajaloolaste uurimustele heideti ette objektivismi ja apoliitilisust. Linnakomitee brigaad leidis instituudi tööd kontrollides, et uuritakse küll näiteks kloostrite ja kirikute arhitektuuri, kuid ei selgitata vene kunsti ja arhitektuuri mõju Eestis jne. Instituudis läbi viidud kontrollreidi tulemustest informeeriti EK(b)P KK propaganda- ja agitatsiooni osakonda. ${ }^{50}$ Kuid sellega ei piirdutud.

1949. aasta sügisel viisid põhjaliku revideerimise sektoris läbi EK(b)P KK partei ajaloo instituudi töötajad Joosep Saat ja Abe Liebman. Nad hindasid sektori uurimistöö plaanis olevate teemade valikut õnnestunuks, kuid nende täitmist pidasid nad täiesti ebarahuldavaks. Ühtlasi avaldasid revideerijad imestust, miks oli H. Kruusil vaja "äärmiselt akuutset ja poliitiliselt tähtsat teemat "Eesti kodanlik riik" palju kitsama teemaga" asendada. Nende arvates olnuks sellise töö ilmumine "ääriselt suure poliitilise tähtsusega sündmus", mis aidanuks "õigesti aru saada kodanliku riigi õigest olemusest" ${ }^{51}$ Ajaloo sektori revideerijad olid aga üsna kindlad, et ka Kruusi välispoliitika ülevaade ei valmi tähtajaks (1950. aasta lõpuks), kuna töö on alles "algstaadiumis ja ajaloosektori juhataja sm A. Vassar vestlusel teadis rääkida, et plaani selle töö kohta ei olevat; käsikirju polevat ka veel näha olnud; käesoleva aasta lõpuks pidavat valmima kuni 1929. aasta lõpuni". ${ }^{52}$

Põhjused, miks Hans Kruus sel moel oma uurimisteemat muutis, ei ole ühemõtteliselt selged. Küllap mängis siin oma rolli Kruusi koormatus administratiivsete kohustustega, mis kaasnesid TA presidendi ja liiduvabariigi välisministri ametikohtadega. Lisaks oli tema õlul arvukalt muidki kohustusi, mis suuresti välistasid sisulise uurimistöö. Režiimile sobiliku ülevaate kirjutamine sõdadevahelise Eesti vabariigi arengust oli aga üsna suur väljakutse, millest Kruus võis ka 1948. aastaks teisenenud poliitilisi olusid silmas pidades teadlikult loobuda. Hoogustuv võitlus nn kodanliku natsionalismiga ei jätnud puutumata 1940. aastal nõukogude võimuga kaasa läinud tegelasi, nagu näiteks Nigol Andresen ja Johannes Semper. H. Kruus pidi mõistma, et temagi positsioon ei saa lõpuni kindel

\footnotetext{
50 Õie Elango, "EK(b)P Keskkomitee 1950.a. VIII pleenum ja ENSV Teaduste Akadeemia", 50 aastat Eesti Teaduste Akadeemiat: $V$ vabariikliku teaduskonverentsi (2.-3. november 1988) materjalid (Tallinn: Eesti Teaduste Akadeemia, 1989), 46.

$51 \quad$ RA, ERAF.247.81.7, 1. 4-5: J. Saadi ja A. Liebmani aruanne, 10.10.1949.

52 RA, ERAF.247.81.7, l. 5: J. Saadi ja A. Liebmani aruanne, 10.10.1949.
} 
olla. Vähetähtis ei ole tõsiasi, et Eesti NSV võimuladvikus asetleidnud võimuvõitluse käigus olid järk-järgult oma positsioone tugevdanud Venemaa eestlased, kel puudus lähem side sõjaeelse Eesti vabariigiga. EK(b)P KK ideoloogisekretäriks tõusnud Ivan Käbin ja tema pooldajad nägid Eesti vabariigi uurimist kompartei ajaloo võtmes.

Siinkohal tuleb oluliste taustateguritena arvestada nii muutusi rahvusvahelisel areenil (külma sõja väljakujunemine) kui ka Nõukogude Liidu sisepoliitilisi arenguid, kus väga jõuliselt toimis läänevastane ("lääne ees lömitajate" paljastamise) kampaania, mille sihiks oli teaduse senisest veelgi jäigem allutamine poliitilise võimu kontrollile. ${ }^{53}$ Tollase Eesti NSV tingimustes tähendas see kampaania eelkõige "kodanliku Eesti" marginaliseerimist ja tollal aktiivselt tegutsenud teadlaste põlu alla panemist. Seda konteksti arvestades mõistis Kruus ilmselt üsna hästi, et ülevaateteose kirjutamine "kodanlikust Eesti riigist" ei pruugi enam muutunud oludes eriti mõttekas olla. Pigem vastupidi - selline käsitlus annaks alust teda kergesti rünnata ja kodanlikuks natsionalistiks tembeldada. Eesti vabariigi välispoliitika oli hoopis ohutum teema, mis andis võimaluse paljastada "klikivalitsuse" nõukogudevastast olemust jms. Pealegi oli Kruusi kasutada ka unikaalne allikmaterjal - Nõukogude Eesti saatkonna dokumendid NSV Liidu välisministeeriumi arhiivist, milledega ta sai 1944. aasta kevadel NSV Liidu välisasjade rahvakomissari Vjatšeslav Molotovi eriloal tutvuda. ${ }^{54}$ Eesti vabariigi välispoliitika teemal oli Kruus varasemalt pidanud ka mitu ettekannet..$^{55}$

H. Kruusi loobumine oma senisest teemast oli märgilise tähtsusega, kuna see tähendas loobumist omariiklusaja terviklikust käsitlemisest. Ja seda mitte ainult ajaloo uurimise perspektiivist vaadatuna, vaid teisigi uurimisvaldkondi silmas pidades. Võrdluseks võib öelda, et kalevi alla pandi

53 Vt selle kohta lähemalt: Tõnu Tannberg, “"Kiri ütleb, et peab tuginema vene teadusele...”. ÜK(b)P Keskkomitee 16. juuli 1947. aasta kinnine kiri professorite N. Kljujeva ja G. Roskini süüasjas ja selle ajaloolisest kontekstist”, Methis, 2o (2017), 168-183.

54 Tõnu Tannberg, «Miks Hans Kruusist ei saanud Eesti NSV välisasjade rahvakomissar juba 1944. aasta kevadel?", Tuna, 3 (2011), 72-87. H. Kruus kirjutas 25. aprillil 1944 Nikolai Karotammele õhinaga: "Kõige põnevam on mulle muidugi töö poliitarhiivis. Suurepärane materjal! Ääretult kasulik mulle ka pooleli oleva töö jaoks: "Eesti kodanlise korra kriis", mille peatükk välispoliitika kohta mul just oli veel kirjutamata. Kuid töö seal läheb siiski väga aeglaselt. Seni olen saanud tutvuda ainult 1,5 aasta materjalidega (1940. ja 1934.a.). Oleks kasulik rakendada abijõudu. Kuid seda praegu ei saa - lubatakse kasutada materjale ainult isiklikult."

55 Hans Kruus, "Kodanliku Eesti välispoliitikast", Postimees, nr. 171-176, 21.--31. juuli 1945; Hans Kruus, "Kodanliku Eesti diktatuurivõimu välispoliitika seoses Teise Maailmasõja sõlme arenemisega 1939.-1940.a.”, Eesti Bolševik, 9, 1947, 30-46. 
ka näiteks sõdadevahelise Eesti kirjanduselu käsitleva koguteose koostamine Eesti NSV TA keele ja kirjanduse instituudis.

Koguteos "Kodaniku Eesti ühiskond ja kirjandus" (18 trükipoognat, esialgne tähtaeg 1948) oli keele ja kirjanduse instituudi jaoks üks olulisemaid tööülesandeid ning pidi esitama "kodanlikul ajal" eesti kirjanduses avaldatud progressiivseid mõtteid ja kriitikat tolleaegse klassivõitluse kohta. Koguteose koostajal ja instituudi esimesel direktoril Daniel Palgil oli siiski tõsiseid raskusi autorite leidmisega ning nendelt kirjatööde kättesaamisega. Nõusoleku kaastööde osas olid alguses andnud Max Laosson, Eduard Päll, Juhan Väinaste ja mitmed teised autorid. Seevastu Nigol Andresen ütles ära talle pakutud teemal "Eesti kirjandus, bolševism ja Nõukogude Liit" artikli kirjutamisest, kuid nõustus hiljem teise teemaga.

Koguteose autorkond saadi siiski lõplikult paika alles 1948. aasta sügiseks ning 30. septembril toimunud diskussioonikoosolekul arutati kavandatava teose sisu. Koguteose autorid ja nende artiklite teemad olid järgmised: Karl Taev "Põhihinnanguid eesti kirjanduse kohta 1917-1940", Arkaadi Uibo "Reaktsiooniline filosoofia ja eesti kirjanikud", Oskar Urgart "Eesti kirjandus formalismi kammitsais", Juhan Väinaste "Tüüpide valiku põhinähtusi”, Bernard Sööt "Kodanluse arvustus eesti kirjanduses”, Eduard Päll "Klassisõja käsitlus kodanliku eesti kirjanduses", Eduard Laugaste "Rahvaluulelised motiivid kodanliku ajastu kirjanduses", Daniel Palgi "Eesti kirjanike võitlus fašismi sissetungi vastu", Aleksander Aule "Kultuurkapitali ja presidendi auhinnad kirjandust suunamas", Villem Alttoa "Kirjandusliku rühmitused Eestis 1920-1940" ja N. Andresen "Natsionalistlik isolatsioon ja internatsionalism eesti kirjanduses". M. Laossonit me enam autorite seast ei leia.

1948. aasta algupoolel oli koguteose küsimus arutlusel ka Eesti NSV TA presiidiumis, kus kohustati asjaosalisi eriti hoolt kandma selle eest, et artiklid oleksid kõrgel ideoloogilis-poliitilisel tasemel. 1949. aastal otsustati aga keele ja kirjanduse instituudi teadustöö plaani kohendamise käigus koguteose "Kodanliku Eesti kirjandus ja ühiskond" koostamisest loobuda. ${ }^{56}$ Ametlikult põhjendati seda asjaoluga, et välisautoreid olevat loobunud oma kaastöödest. Kuid on selge, et oma osa etendas siin kindlasti nn kodanlike natsionalistide vastane kampaania, kus üheks märklauaks oli ka D. Palgi.

Alates 1949. aasta lõpukuudest teravnesid ka H. Kruusi vastased süüdistused, mis tõid järgmise aasta alguskuudel kaasa tema parteist väljaheitmise ning vallandamise välisministri ja TA presidendi ametikohalt. 1950.

56 Eva Ahven, Pilk paberpeeglisse: Keele ja Kirjanduse Instituudi kroonika 1947-1993 (Tallinn: Eesti Keele Sihtasutus, 2007), 31-32, 46, 66. 
aasta EK(b)P KK 8. pleenumil ja sellele järgnenud ulatuslikes süüdistus- ja paljastuskampaaniates sai Hans Kruusist lausa kodanlik natsionalist number üks. 1950. aasta oktoobris Kruus arreteeriti. ${ }^{57}$

Hans Kruusi langusega lagunes laiali senine ajaloouurimise korraldus ning enamik tema nimega seotud "projekte" tasalülitati. Nii läks ka "Lühikese Eesti ajaloo" I köite käsikirjaga. Hans Kruus andis selle teose peatoimetajana 1949. aasta novembris Eesti NSV TA toimetus-kirjastusnõukogu vastutavale sekretärile F. Roosele üle raamatu käsikirja kolmes eksemplaris. Roose saatis käsikirja 16. novembril 1949. aastal edasi Eesti NSV TA ajaloo instituudi direktorile Richard Kleisile, lisades saadetisele ka omapoolsed märkused käsikirja kohta. Õigupoolest olid need kahesugused: osa oli tehtud käsikirja teksti ning teistele juhiti tähelepanu eraldi kirjalikus retsensioonis. F. Roose retsensiooniga oli tutvunud ka H. Kruus ja selle heaks kiitnud. Tema 15. novembriga dateeritud seisukoht leidub retsensiooni äärel: "Sm. Kleisile. Sm. Roose märkused väärivad tähelepanu. Palun sm. Mooral ${ }^{58}$ neid koos teistega kaaluda ja vajaduse korral teha tekstis vajalikke muudatusi - kulutades selleks mitte üle kolme päeva. Teine eks. palun kohe kirjastusele üle anda ja hoolitseda, et "LEA" kallal kirjastuses töö kohe algaks. Eessõna esitan jaanuaris 1950." 59

Käsikirja trükkiandmisega oli tõepoolest kiire, sest esialgselt loodeti see üllitada poliitiliselt oluliseks tähtpäevaks - Eesti NSV 10. aastapäevaks. Küllap H. Kruuski lootis, et selle raamatu avaldamine aitaks temale suunatud süüdistusi hajutada. Ta kirjutas 1950. aasta alguskuudel raamatule pika saatesõna, mis oli ühtaegu tema enda kui "kodanliku" ajaloolase patukahetsus, kuid selleks ajaks oli tema saatus juba otsustatud. ${ }^{60}$ Kuigi formaalselt tegeleti teose trükiks ettevalmistamisega ka pärast EK(b)P KK 8. pleenumit ning lepiti kokku käsikirja arutelu Moskvas NSV Liidu TA ajaloo instituudis, oli tegelikult selle väljaande saatus lõplikult otsustatud eelkõige just seetõttu, et Hans Kruus oli selle üldkäsitluse peatoimetajaks. Pärast 1950. aasta aprillis Viktor Maamäe ja Artur Vassara sulest ilmunud n-ö programmilist artiklit oli kõigile selge, et Kruus on lõplikult põrmustatud. ${ }^{61}$ Samade autorite 1950. aasta suvel avaldatud artiklis tõdeti: “Kodanlik

57 Vt Hans Kruusi languse kohta lähemalt Kivimäe, Rektor Hans Kruus, 164-172.

58 Eesti NSV TA ajaloo instituudi arheoloogia sektori juhataja Harri Moora.

59 Tallinna Ülikooli Akadeemiline Raamatukogu, Baltica osakond, MSC K-1 208, 1. 1-4:

F. Roose. Märkused "Lühikese Eesti ajaloo I" käsikirja kohta, 14.11.1949.

60 RA, ERAF.247.81.40: "Lühikese Eesti ajaloo" I köite eessõnaks kirjutanud Hans Kruus. Tõenäoliselt lõpetas H. Kruus selle saatesõna 1950. aasta veebruaris.

${ }_{61}$ Artur Vassar, Viktor Maamägi, "Eesti kodanlike natsionalistide vaenulikust tegevusest ajalooteaduse alal”, Rahva Hääl, 28. aprill 1950. 
natsionalist $\mathrm{H}$. Kruus püüdis nurja ajada ka kodanluse diktatuuri ajajärgu teaduslikku uurimist."'62

Tõepoolest, Hans Kruusi "kodanikuks natsionalistiks" tembeldamine tõi kaasa selle, et 1950. aastaks tõrjuti Eesti NSV TA instituutide tööplaanidest Eesti vabariigi perioodi puudutavad sisulisemad teemad välja. Kruusi-vastaste süüdistuste üheks põhipunktiks saigi etteheide sellest, et "võtnud enda peale kodanliku diktatuuri uurimise" ei teinud ta selleks tegelikult midagi, vaid organiseeris "töö Eesti NSV Teaduste Akadeemia Ajaloo Instituudis nii, et takistada selle perioodi uurimist ka tulevikus". ${ }^{63}$ Kogu omariikluse aeg muudeti marginaalseks uurimisperioodiks, mille käsitlemisel olid lubatud vähesed kitsamad teemad (töölisliikumine, kommunistide tegevus, agraarolud, välispoliitika nõukogudevastasus jms) ning mida sai teha ainult negatiivses võtmes.

Eitav suhtumine Eesti vabariigi perioodi saavutas oma apogee 1952. aastal ilmunud esimeses nõukogulikus, täpsemalt öeldes - stalinistlikus, üldkäsitluses. ${ }^{64}$ Selle väljaande aluseks oli EK(b)P KK otsus 1950. aasta septembrist, millega kiirkorras kohustati ajaloo instituuti välja andma üheköiteline Eesti ajalugu, nüüd juba lõplikult nimetuse all "Eesti NSV ajalugu”. Gustav Naan oli veendunud: "Kruusi ja tema käsilaste kõrvaldamine ajaloorindelt lõi vajalikud tingimused ajalooalase uurimistöö arendamisele kiirendatud tempos". ${ }^{65}$ Uue üldkäsitluse koostamist hakkaski nüüd juhtima R. Kleisi järel ajaloo instituudi direktoriks saanud Gustav Naan ning tema kõrval Viktor Maamägi, kellest järgnevatel aastatel sai ajalooteaduse keskne figuur Eesti NSV-s. ${ }^{66}$ Pärast G. Naani valimist 1951. aastal Eesti NSV TA liikmeks ja lahkumist ajaloo instituudi direktori kohalt edutati asutuse etteotsa V. Maamägi ${ }^{67}$, kes jäi sellele ametipostile 1968. aastani. 1950. aastal teravalt $\mathrm{H}$. Kruusi vastu välja astunud A. Vassar säilitas Eesti ajaloo sektori juhataja koha ning jätkas samuti uue üldkäsitluse Eesti ajaloo

\footnotetext{
62 Viktor Maamägi, Artur Vassar, "Kümme aastat ajalooteadust Nõukogude Eestis", Nõukogude teaduse arengust Eesti NSVs 1940-1950 (Tallinn: Eesti Riiklik Kirjastus, 1950), 31.

63 Gustav Naan, "Eesti ajaloo võltsimisest kodanike natsionalistide poolt", Rahva Hääl, 12. detsember 1950.

64 Vt. 1952. aasta üldkäsitluse koostamise kohta lähemalt Kuuli, Eesti ajaloo kirjutamisest Stalini ja Hruštšovi ajal, 25-35. Ka selle väljaande puhul kõneldi alguses õpikust, kuid raamatu väljaandmise lõppfaasis sellest loobuti.

65 Naan, "Eesti ajaloo võltsimisest kodanike natsionalistide poolt".

66 Eesti omariikluse perioodi ajalugu 1952. aasta üldkäsitluses ning selle edasine uurimine Eesti NSV-s väärib kindlasti omaette uurimust.

67 Ta juhtis ajutise kohusetäitjana ajaloo instituuti aprillist septembrini 1950. aastal.
} 
varasema ajaloo põhiautorina. Eesti omariikluse perioodi pisutki sisulisem uurimine sai võimalikuks aga alles 1960. aastatel.

Aвstract: On the study of the period of the Republic of Estonia at the Estonian SSR Academy of Sciences Institute of History in 19461950

A decision adopted on 30 October 1944 in Moscow by the Orgburo of the Central Committee of the Communist (Bolshevist) Party of the Soviet Union (hereinafter C(B)PSU CC) launched an extensive process of sovietisation in the Estonian SSR. The 'great struggle' against so-called bourgeois nationalism began, and one of its thrusts was aimed at vilifying the prewar Republic of Estonia and rooting it out of society's consciousness. History started playing an important role in this 'struggle'. This was already stressed at the Estonian Communist (Bolshevist) Party (hereinafter EC(B) P) CC plenary meeting held in early December of 1944, where Moscow's decision was discussed along with the first measures for launching the sovietisation of society. At the meeting, a programmatic speech was given by Hans Kruus, the founder of historical science focusing on the Estonian nation, who began to serve the Soviet regime in the 'June coup' of 1940. In 1944, Kruus was a close associate of Nikolai Karotamm, the leader of the Estonian SSR at that time, and he led the sovietisation of historical science, and more broadly of the whole system of scientific and academic research in Estonia.

Hans Kruus formulated the aims and tasks of historical science in Soviet society and also considered it necessary to study the period of independent statehood. He understood perfectly that the assessment from Marxist positions of the legacy of the era of independence was essential for educating the 'new Soviet man', but also for making the Soviet regime as palatable as possible for society. For this reason, Karotamm and his 'team' paid a great deal of attention to involving writers, scientists and other people known in society to a greater or lesser extent in carrying out the sovietisation process. Kruus stressed the need to eliminate the 'remnants of misconceptions' left 
by the 'era of bourgeois Estonia', but this did not mean casting the era of independent statehood into the trash bin of history. The task of historical science was to give the 'bourgeois Estonian state' Soviet content.

One of the first practical tasks in sovietising historical science was to work out a Marxist periodisation for Estonian history, which was supposed to be founded on the theory of social-economic formations. Artur Vassar was the historian who dealt the most with questions of periodisation, completing his system by 1947. Additionally, Abe Liebman, the head of the Chair of History at the Estonian republic's EC(B)P CC Communist Party School, and Gustav Naan, who at that time was studying at the C(B)PSU CC Higher Communist Party School in Moscow, worked out their own periodisation system. These two competing systems were combined into a single unified system through the mediation of Ivan Käbin, the EC(B) P CC Propaganda and Agitation Secretary, and it was published in the magazine Eesti Bolševik [Estonian Bolshevik] in September of 1948. The publication of the Soviet periodisation system in 1948 was an important landmark in the sovietisation of historical science, since the main periods of Estonian history based on social-economic formations were introduced to the public for the first time. Although this periodisation system was later refined and expanded, it remained the basis for future historical works and provided the framework for the study of history in the Estonian SSR for many years to come.

Naturally, the aim of the regime was also to sovietise the organisation of science. The central undertaking in this process was the founding of the Estonian SSR Academy of Sciences in 1946. Here as well, the key figure was Hans Kruus, who became the Academy's first president and a corresponding member of the Academy of Sciences of the Soviet Union. Various academic institutes began operating as sub-institutions of the Academy of Sciences. These institutes had the leading role in academic research, unlike institutions of higher education, which were expected to prepare students for research and academic degrees and not to contribute to research as their primary task. The Estonian SSR Academy of Sciences Institute of History (directed by Richard Kleis) became the central research institution for historical science (together with archaeology and art history).

The compilation of Marxist survey works on Estonian history, which were also supposed to provide a complete overview of the period of the independent Republic of Estonia, became the primary task of the Institute of History. Its primary aim at that time was to write an Estonian history textbook, but the undertaking failed. Thereafter plans were made to 
produce a two-volume Lühike Eesti ajalugu [Brief History of Estonia]. The manuscript for the first volume was ready to be printed by the end of 1949. The institute also started compiling a new three-volume Soviet-style general treatment of Estonian history. The manuscript for the first volume was supposed to be completed in 1948, the second volume in 1950 and the third volume in 1951. Hans Kruus was the executive editor of both publications.

In studying the period of the independent Republic of Estonia, chief attention had to be paid to the labour movement, though initially there were also more substantial studies of the period of independent statehood planned in the Institute of History. Namely, Hans Kruus planned to write the book Eesti kodanlik riik 1918-1920 [The Estonian Bourgeois State 19181920], which was supposed to provide a 'general popular-style overview of the class nature of the bourgeois Estonian state, its economic foundations, the struggles between cliques that developed in it, and foreign policy'. After a few years, Kruus abandoned this theme and set a new objective for himself to write the book Kodanliku Eesti välispoliitika 1918-1940 [The Foreign Policy of Bourgeois Estonia 1918-1940]. Yet even this undertaking did not come to fruition since the political conditions had already been significantly altered by the end of the 1940s. The campaign against so-called bourgeois nationalism was picking up steam and it did not leave those who went along with the Soviet regime in 1940 untouched. From late 1949, Hans Kruus became the primary target of this campaign, which led to his expulsion from the Communist Party, the dismissal from the posts of Minister of Foreign Affairs and President of the Academy of Sciences, and eventually to his arrest in October of 1950.

The organisation of historical research disintegrated with the fall of Kruus, and most of the projects connected to his name were cancelled. His stigmatisation as a 'bourgeois nationalist' led to the more substantial themes concerning the period of the independent Republic of Estonia being squeezed out of the work plans for the Estonian SSR Academy of Sciences institutes by 1950. One of the main points in the accusations levelled against Kruus became the reprimand that 'having taken it upon himself to study the bourgeois dictatorship', he actually did not do anything to launch this research, but rather organised 'the work in the Estonian SSR Academy of Sciences Institute of History in such a way as to prevent the study of this period in the future as well'. The entire era of independent statehood was turned into a marginal period of research. A few narrow themes were permitted in its research, such as the labour movement, the activities of the Communists, agrarian conditions, and opposition to the Soviet Union in 
foreign policy. The negative attitude towards the independent Republic of Estonia achieved its apogee in the first Soviet, more precisely Stalinist, general survey of Estonian history published in 1952.

KEYwORDs: Estonian history, sovietisation of historical science, history of science, periodization, political campaigns, loss of independent statehood, repression of intellectuals.

Tõnu Tannberg (b. 1961) is Professor of Estonian History, Institute of History and Archaeology, University of Tartu.*

* Correspondence: Institute of History and Archaeology, University of Tartu, Jakobi 2, 51004, Estonia. E-mail: tonu-andrus.tannberg@ut.ee 